\title{
Research Paper: \\ The Extracts of Epilobium Parviflorum Inhibit MCF-7 Breast Cancer Cells
}

\author{
Behnaz Hatefi Kia $^{1}$ (D), Sakineh Kazemi Noureini ${ }^{1 *}$ (D), Mohammad Reza Vaezi Kakhki ${ }^{1}$ (D)
}

1. Department of Biology, Faculty of Basic Sciences, Hakim Sabzevari University, Sabzevar, Iran

\begin{tabular}{|l|l|}
\hline $\begin{array}{l}\text { Use yourdevice tosan } \\
\text { and read the artice online }\end{array}$ & $\begin{array}{l}\text { How to cite this paper Hatefi Kia B, Kazemi Noureini S, Vaezi Kakhki MR. The Extracts of Epilobium Parviflorum Inhibit } \\
\text { MCF-7 Breast Cancer Cells. Iranian Journal of Toxicology. 2021; 15(1):65-72. http://dx.doi.org/10.32598/ijt.15.1.752.1 }\end{array}$ \\
\hline
\end{tabular}

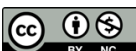

Article info:

Received: 21 Sep 2020

Accepted: 17 Dec 2020

Online Published: 01 Jan 2021

* Corresponding author:

Sakineh Kazemi Noureini, PhD. Address: Department of Biology, Faculty of Basic Sciences, Hakim Sabzevari University, Sabzevar, Iran. E-mail: kazemibio@gmail.com

\section{A B STRACT}

Background: Traditional medicine is inspiring in drug development research. Epilobium parviflorum extracts have shown promising therapeutic effects on prostate cancer cells. The similarities between breast and prostate cancers at molecular and metabolic levels prompted us to explore its effects on human breast cancer.

Methods: The root, aerial parts and flowers of the plant were, collected and dried separately at ambient temperature and away from direct sunlight. The aquatic and methanolic extracts of each part was prepared. The effect of each extract on the growth of MCF-7 breast carcinoma cells and HEK293 normal cell line was evaluated, using MTT assay. Each experiment was repeated at least three times independently. The IC50 values for each treatment time point were analyzed, using ANOVA at $\mathrm{P}<0.05$.

Results: While none of the extracts had considerable toxicity on normal HEK293 cells, some of them showed varying levels of toxicity on the MCF-7 cells. The methanolic extracts were more cytotoxic than the aqueous counterpart. The roots' methanolic extract showed the strongest cytotoxicity on the MCF-7 cells in a dose and exposure time dependent manner. The IC50 after 48 hours of treatment was determined at $73 \mu \mathrm{g} / \mathrm{ml}$.

Conclusion: This study is the first to demonstrate that Epilobium parviflorum had a strong growth inhibiting property on MCF-7 cell line, as a potential model to treat human breast cancer cells. The most cytotoxic effect was noted for the methanolic root extract. Determination of the effective biochemical constituents of the extract against cancer cells is the focus of our future research.

Keywords: Epilobium parviflorum, Anti-cancer effect, Aquatic and methanolic extracts, MCF-7 cell line, Breast cancer

\section{Introduction}



ancer is the second leading cause of death after cardiovascular disease worldwide. The lung, rectal, breast and prostate cancers are among the highest fatal cases in humans globally [1]. In developing countries, breast cancer is the first leading cause of cancer deaths among women [2]. The current therapeutic strategies to treat cancer, such as radiation and chemotherapy, have many side effects and developing drug resistance in enduring cancer cells make the procedure even more complicated.

Since there is no definitive cure for cancer, developing cancer preventive strategies is essential in the management of this disease. One of the most promising strat- 
egies in anticancer drug development is searching for natural compounds in traditional medicine [3]. Iran is rich in herbal species due to its climatic diversity and traditional medicine history, which has been mostly relied on herbal treatments. Among the 20 identified Epilobium willow species in Iran, Epilobium parviflorum (E. parviflorum) was selected for investigation in this study due to its proven effects on prostate cancer [4].

This plant is a perennial herb belonging to the Onagraceae family and grows at various geographic locations in Iran, reaching an average height of $30-80 \mathrm{~cm}$. The habitat of this plant spans across the mountainous altitudes in Khorasan, Mazandaran, Damavand and East Azerbaijan [4-7]. The upright stem is densely covered with hairs, especially denser in the lower part. The $4-10 \mathrm{~cm}$ long leaves grow opposite each other, un-stalked, oblong oval and toothed, rounded at the base. The tiny flowers with four petals, eight stamens and a 4-lobed stigma are pale pink or purple, usually blooming from June to August. The fruit is a $3-7 \mathrm{~cm}$ long capsule, containing very small black seeds with white fibers that comfort the dispersal by wind [8].

The extracts of this plant, with antioxidant and antiinflammatory effects, are used in traditional medicine for healing illnesses of prostate, bladder and kidneys [9]. E. parviflorum has been prescribed as tea in traditional medicine to treat several complaints including the disorders of kidneys and urinary tract [10]. The extracts have been shown to inhibit the proliferation of human prostate cells in vitro by affecting the progression of cell cycle. The extract has been known for its antioxidant and antiinflammatory effects on benign prostatic hyperplasia and prostatitis [11]. It also reduces the effects of cyclooxygenases COX-1 and COX-2, which catalyze the biosynthesis of prostaglandins $[11,12]$.

In the COX inhibition assay, E. parviflorum has strongly reduced the PGE2 secretion with an IC50 of $1.4 \pm 0.1 \mu \mathrm{g} / \mathrm{mL}[12]$. The aqueous extract, the essential oil and the remaining aromatic water have shown strong antimicrobial effects against a number of bacteria and fungi, including Staphylococcus aureus, Enterococcus faecalis, Escherichia coli, Pseudomonas aeruginosa and Candida albicans, with a minimum inhibitory concentration of $10-40 \mu \mathrm{g} / \mathrm{ml}[13]$.

The published pharmacological reports on this plant indicate the presence of flavonoids and sitosterol derivatives that inhibit Prostaglandin (PG) biosynthesis and reduce inflammation in experimental animals [14]. The anti-proliferative effect of the extracts has been reported on human prostate mucosa PZ-HPV-7, by arresting cell cycle progression from the G0/G1 phase. Another relevant effect reported for the extract is the inhibition of 5-alpha reductase and aromatase enzymes [15]. The aquatic and alcoholic extracts of this plant are also effective in inducing apoptosis in human prostate LNcap cells through disruption of mitochondrial membrane potential and caspase- 3 activation $[9,16]$.

The compounds extracted from the aqueous extract of this plant include mostly polyphenols and flavonoids, including oenothein B [9], macrocyclic tannin, camphoric acid, chlorogenic acid, gallic acid derivatives, oleic acids, myricetine, Kaempferol and other glycosides [11, 17]. The Kaempferol and quercetin constituents of this plant have shown antiproliferative effects [15]. Oenothein B has anti-inflammatory, antiviral and antitumor properties $[10,15,19]$. Interestingly, enzymatic metabolites have been identified in the extract of E. parviflorum that contain aromatase and 5-alpha-reductase inhibitors. These compounds have been shown to strongly inhibit prostate cancer $[9,20]$.

Investigating the anti-cancer properties of E. parviflorum, especially in breast cancer is the particular focus of this study. As briefly reviewed above, the only cancer type known to be controlled with the extract of this plant so far, is prostate cancer. To date, no information has been reported on the effects of the alcoholic or aqueous extracts of E. parviflorum on breast cancer cells. Considering that the hormonal dependence of most breast cancers is closely similar to that of benign prostate cancer, we aimed to investigate whether MCF-7 cells, as a model cell for hormone-sensitive breast cancer, may be inhibited by the aquatic and/or methanolic extracts of E. parviflorum.

\section{Materials and Methods}

Preparation of plant samples: The samples of E. parviflorum were collected manually from Neyshabour area. Its components, i.e., the roots, aerial parts and flowers, were dried separately in the shade. After complete drying, they were individually pulverized to enhance the extraction efficiency in the solvents.

Extraction: Five grams of the powder from each plant part was added to $100 \mathrm{ml}$ of $80 \%$ methanol or double distilled water, and shaken for 24 hours with a rotation speed of $250 \mathrm{rpm}$ at room temperature. The solutions were filtered through whatman paper filter under vacuum and placed in a rotary apparatus at a speed of $70 \mathrm{rpm}$ at $40^{\circ} \mathrm{C}$ for 24 hours. The solutions were finally transferred to an oven at $45^{\circ} \mathrm{C}$ and kept for 24 hours to completely remove the solvents [21]. The stock solu- 
tions of each extract was prepared at $25 \mathrm{mg} / \mathrm{ml}$, sterilized through filter and stored at $-20^{\circ} \mathrm{C}$ until further analysis.

Cell culture: The breast cancer cell line (MCF-7) and/ or HEK293 normal cell line were cultured in DMEM medium, containing $10 \% \mathrm{FBS}, 1 \%$ penicillin-streptomycin at $37^{\circ} \mathrm{C}, 5 \% \mathrm{CO}_{2}$ and $95 \%$ humidity. The culture medium was changed every 48 hours and the cells were sub-cultured at $80 \%$ confluence, and removed from the culture dishes with trypsin-EDTA every 4-5 days [22].

MTT assay: The potential effects of the extracts on cellular growth were estimated, using MTT assay [22]. Approximately 10,000 cells were seeded in each well of 96-well culture plates. The next day, the cells were treated with fresh medium, containing 1000, 500, 250, 125, 62.5 or $31.25 \mu \mathrm{g} / \mathrm{ml}$ of the extracts, and incubated for 24 , 48 or 72 hours. The cells were then incubated for 4 hours in the presence of $0.5 \mathrm{mg} / \mathrm{ml}$ MTT (Sigma-Aldrich; Germany) at $37^{\circ} \mathrm{C}$. The viable cells metabolically converted the 3-(4,5-dimethylthiazol-2-yl)-2,5-diphenyltetrazolium bromide to its insoluble formazan dye (i.e., purple to violet dye), which was then dissolved in $100 \mu 1$ dimethyl sulfoxide. The concentration of the dye was estimated by reading the absorbance at $570 \mathrm{~nm}$ on a plate reader (Powerwave, BioTek, Germany) [9]. The experiments were repeated at least three times independently, each including four replicates of every extract concentration.

Statistical analyses: The statistical analyses were performed, using SPSS v. 19. In this study, T-test analysis was done for every two independent groups. Independent samples were used to compare the significance of cell viability in breast cancer cells versus normal cells for each extract over 48 hours of treatment. The twoway ANOVA was applied to test the influence of two different categorical independent variables on one con- tinuous dependent variable. This was done to assess the main effect of each independent variable and whether there was an interaction between them. Two-way ANOVA was used to compare the survival rate of normal versus cancer cells at different time periods of the roots' methanolic extract treatments. Factor A was the treatment exposure time and factor B was the concentration of the extract used [25].

\section{Results}

Citotoxicity effects: The cytotoxicity of the aquatic and methanolic extracts of E. parviflorum was evaluated using MTT assay. Six different concentrations of the extracts were tested on the breast cancer and/or HEK293 normal cells. Figure 1 represents the cells viability after 48 hours of exposure to various treatments. A dose-dependent relationship of decreasing viable cells was demonstrated when MCF-7 cells were treated with the methanolic extracts, although no significant changes was observed on normal cells viability (Figures 1A, B $\&$ C). Among the methanolic extracts, the one derived from the plant roots were the most cytotoxic with the IC50 value being $73 \mu \mathrm{g} / \mathrm{ml}$. The extracts from the other plant parts were significantly less cytotoxic. The IC50 values for the methanolic extract of the flowers and aerial parts were $110 \mu \mathrm{g} / \mathrm{ml}$ and $160 \mu \mathrm{g} / \mathrm{ml}$, respectively. Based on the t-test analysis, the inequality of variances was at the $5 \%$ level and the significant differences for each of the methanolic extracts was less than 0.05 (P $<0.05$ ). None of the methanolic extracts showed significant cytotoxicity against HEK293 cells. Also, none of the aqueous extracts showed significant cytotoxicity on either cell types (Figures 2A, B \& C).

Cell viability versus the extracts: Figure 2 shows the estimated viability for MCF-7 and HEK293 cells after 48
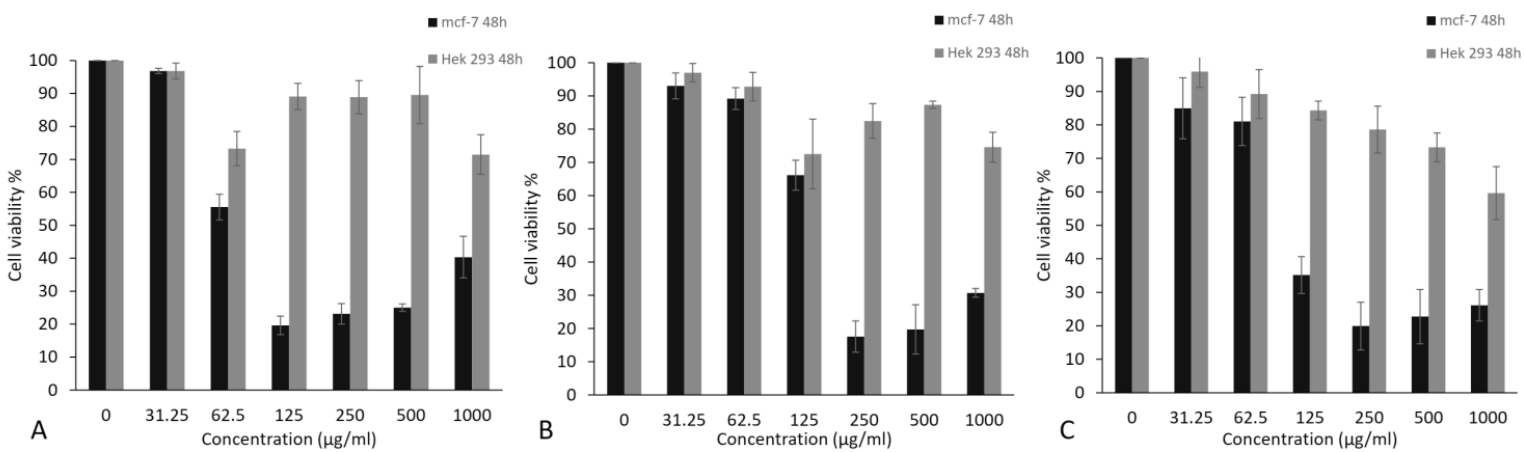

Figure 1. The cells viability after 48 hours of exposure to various treatments

A. Viability of the MCF-7 and HEK293 cells after 48 hours treatment with methanolic extract of root; B. Aerial parts; and C. Flower; The Mean \pm SEM values of three independent experiments. 

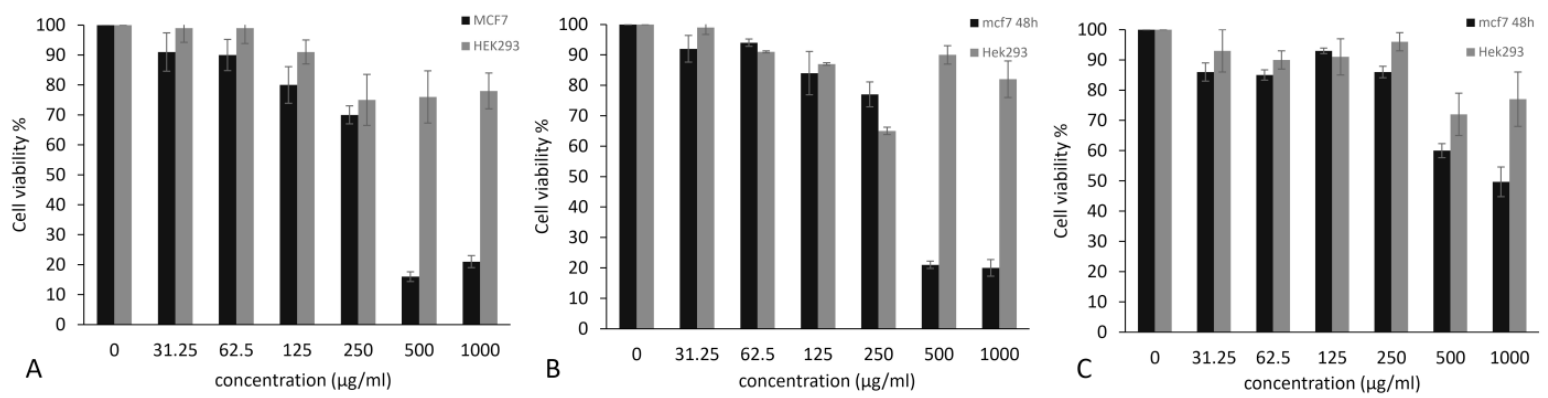

Figure 2. The estimated viability for MCF-7 and HEK293 cells after 48 hours

A. Viability of the MCF-7 and HEK293 cells after 48 hours treatment with aqueous extract of root; B. Aerial parts; and C. Flower; The Mean \pm SEM values of three independent experiments

hours of treatment with the aqueous extracts, using MTT method. The IC50values of the aqueous extracts of the roots, aerial parts and flowers of E. parviflorum on MCF7 cells were measured as 330,460 and $600 \mu \mathrm{g} / \mathrm{ml}$, respectively. Again, these extracts had no substantial cytotoxicity on HEK293 cells. In general, the aqueous extracts showed much less inhibitory effects on both cancer and normal cells as compared with those for the methanolic extracts. The t-test results showed that the inequality of variances was at $1 \%$ level and no significant differences were observed among the aqueous extract. As the survival percentage of cells treated with the methanolic extract of the roots was the lowest among the other five extracts, the cell viability tests for various exposure times were performed for the strongest extract. Figure 3 summarizes the MTT measurements of the cell viability for three independent experiments, each consisting of four replicates for every concentration of the extracts.
The methanolic root extracts of E. parviflorum showed a dose and exposure time dependent cytotoxicity effects on MCF-7 cells (Figure 3). The IC50 values for the methanolic root extract on MCF-7 cells after 24, 48 and 72 hours of treatment were 130, 73 and $52 \mu \mathrm{g} / \mathrm{ml}$, respectively. Based on the one-way ANOVA of the survival rates at three time points, the significance of the IC50 values were confirmed $(\mathrm{P}<0.05)$. Also, the $\mathrm{P}$ value for Factor $\mathrm{A} * \mathrm{~B}$ was 0.0012 after 48 hours of treatment.

\section{Discussion}

Cancer progression is believed to be very closely linked to increased inflammation and oxidative stress. Therefore, the combination of anti-inflammatory and antioxidant properties may enhance the anti-cancer effects of the drugs [24]. Plants of Epilobium species have many antioxidant and anti-inflammatory properties, arising from their active metabolites with pharmacological

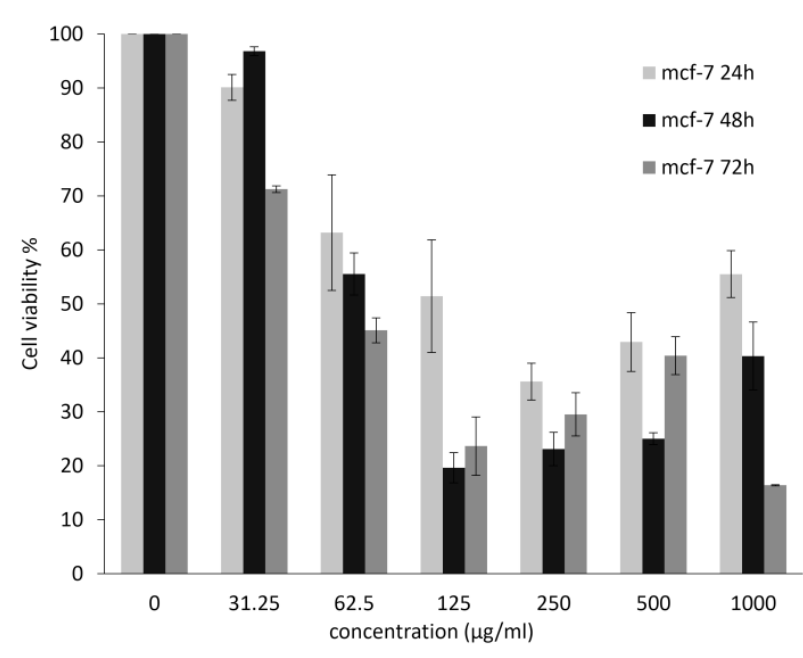

Figure 3. Viability of MCF-7 cells in various time points of exposure to the methanolic extract of root of Epilobium parviflorum; The Mean \pm SEM values of three independent MTT experiments. 
effects that include anticancer properties [4]. In spite of several important active compounds including falvonoids, ellagitanins, aromatic acids and sterols identified in E. parviflorum, its anticancer properties have been poorly studied. This plant is well known for its therapeutic effects on prostate diseases $[9,16]$. However, its potential anti-proliferative and cytotoxic effects on breast cancer cells have not been studied based on our recent literature review. This study reports the inhibitory effect of E. parviflorum on breast cancer cells for the first time.

This study was conducted to investigate whether the aquatic and/or methanolic extracts of E. parviflorum may have inhibitory effects against MCF-7 cancer cells. We found that the roots were the most cytotoxic part of this plant, which contained high amounts of metabolites. We used two different solvents to prepare the extracts, methanol and distilled water. Some of the substances in the methanolic extracts have been previously identified, including alkaloids, flavonoids, ellagic acid and various tannins with known therapeutic effects [25]. In this regard, E. Parviflorum has been shown to contain myricetin, quercetin and isomyricetine, kaempferol and chlorogenic acid [17].

The high antioxidant and protective capacity of this plant are believed to be due to its flavonoid constituents [18, 26]. Among various metabolites of the aqueous extracts of E. parviflorum, several have recently been reported to have antioxidant activity and inhibit lipo-oxygenase, due to their strong radical scavenging activity [27]. These anti-oxidatant properties may explain the non-cytotoxicity of the aqueous extracts found in the current study. Another active compound of this plant is $\beta$-cytosterol that is capable of binding estrogen and androgen receptors to exert agonist effects on steroid receptors [18]. We found weak cytotoxic effects of the aqueous extracts on MCF7 cells compared to the methanolic extract. However, in a previous study [16], the aqueous extracts inhibited the proliferation of hormone-dependent prostate cancer cells LNCaP at a comparable concentration (IC50=37.3 $\mu \mathrm{g}$ / $\mathrm{ml})$. This could be related to different molecular aspects of hormone metabolism between the two cell lines.

The most detailed report on the cytotoxic effects of this plant comes from Hevesi's studies on prostate cancer cells in vitro $[18,28]$. Another recent study reported the therapeutic effects of the extract on Benign Prostatic Hyperplasia (BPH) in rats [29]. The therapeutic effects are believed to be associated with androgen regulation, suppressing $\mathrm{NF}-\kappa \mathrm{B}$ expression, reducing inflammatory responses and oxidative stress [30-32]. Oenothein B as a main compound of this plant, inhibits aromatase and 5- $\alpha$-reductase enzymes [33], inactivates endopeptidases, and suppresses growth factors [32]. Although secondary metabolites from the root extract have not been well studied, our data provide strong evidence in support of the cytotoxicity of the methanolic extract, compared to the aqueous ones. The finding may imply a higher anti-cancer capacity in the roots of E. parviflorum than in other parts of the plant.

\section{Conclusions}

Reviewing the evidence reported by recent studies on various biological effects of E. parviflorum, in particular its anti-cancer effects, we tested the hypothesis that whether the plant may inhibit the growth of MCF-7, a hormone sensitive breast cancer cell line. To our knowledge, this is the first report on the anti-cancer effect of the plant extracts against a well defined breast cancer cell line. Our results indicated that the methanolic extracts of E. parviflorum had stronger cytotoxic effects than the aqueous ones without having a considerable damaging effect on a normal cell line model. The methanolic extract had a strong inhibitory effect on MCF-7 cell line, which was dependent on the dose and exposure time. The extracts did not affect the growth and proliferation of a normal cell model, i.e. HEK 293 cell line.

\section{Ethical Considerations}

\section{Compliance with ethical guidelines}

Ethical considerations were not applicable as this study focused on an in vitro research model only.

\section{Funding}

The present paper was extracted from the MSc. thesis of the first author, Department of Biology, Faculty of Basic Sciences, Hakim Sabzevari University, Sabzevar, Iran.

\section{Author's contributions}

All authors contributed in preparing this article.

\section{Conflict of interest}

The authors declared no conflicts of interest.

\section{Acknowledgements}

The authors appreciate the support and laboratory facilities provided by Biotechnology Research Center at Hakim Sabzevari University in Sabzevar, Iran. 


\section{References}

[1] Brawley OW. A brief history of the American cancer society extramural research program. CA Cancer J Clin. 2013; 63(1):9-10. [DOI:10.3322/caac.21169] [PMID]

[2] Aghaabbassi K, Hassani KH, Askari N, Torkzadeh Mahani M, Ramzani Ghara A. [Anticancer activity of Blepharis persica seed hydroalcoholic extract on (MCF-7) human breast cancer and (LNCaP) prostate cancer cell lines and its synergistic effect with doxorubicin (Persian)]. J Cell Tissue. 2019; 9(3):206-21. http:/ /jct. araku.ac.ir/article_34388.html?lang=en

[3] Schepetkin IA, Ramstead AG, Kirpotina LN, Voyich JM, Jutila MA, Quinn MT. Therapeutic potential of polyphenols from Epilobium Angustifolium (Fireweed). Phytother Res. 2016; 30(8):1287-97. [DOI:10.1002/ptr.5648] [PMID] [PMCID]

[4] Vitalone A, Allkanjari O. Epilobiumspp: Pharmacology and phytochemistry. Phytother Res. 2018; 32(7):1229-40. [DOI:10.1002/ptr.6072] [PMID]

[5] Hosseini M, Rahim Forouzeh M, Barani H. Identification and investigation of ethnobotany of some medicinal plants in Razavi Khorasan province. J Med Plants. 2019; 18(70):212-31. [DOI:10.29252/jmp.2.70.212]

[6] Naqinezhad A, Mokhtari S, Joharchi MR. [A contribution to flora, life form and chorology of plants of political boundary mountains of Arzaneh - Taybad, Khorassan-e Razavi (Persian)]. J Plant Res. 2015; 28(1):199-209. http:/ / plant.ijbio.ir/article_669. html?lang=en

[7] Naqinezhad A, Ramezani E, Khalili AH, Joosten H. Habitat and floristic peculiarities of an isolatedmountainmirein the Hyrcanianregionof northern Iran: A harbor for rare and endangered plants pecies. Mires Peat. 2019; 24(21):1-22. [DOI:10.19189/ MaP.2017.OMB.321]

[8] Pignatti S. Conservation of endangered species: Androsace mathildae Levier (Primulaceae) in Central Italy. Flora d'Italia. 1982; 2:155. https://www.scirp.org/ (S(czeh2tfqyw2orz553k1w0r45))/reference/ReferencesPapers aspx?ReferenceID=1628761

[9] Kiss A, Stolarczyk M, Piwowarski JP, Granica S. Effects of standardized extracts from Epilobium sp. herbs on of hormonedependent prostate cancer cells (LNCaP)-searching for active compounds. Pharmacol Rep. 2013; 65(1):1-13. [DOI:10.1016/ S1734-1140(13)71277-5]

[10] Coulson S, Rao A, Beck SL, Steels E, Gramotnev H, Vitetta L. A phase II randomised double-blind placebo-controlled clinical trial investigating the efficacy and safety of prostate EZE max: A herbal medicine preparation for the management of symptoms of benign prostatic hypertrophy. Complement Ther Med. 2013; 21(3):172-9. [DOI:10.1016/j.ctim.2013.01.007] [PMID]

[11] Steenkamp V, Gouws MC, Gulumian M, Elgorashi EE, van Staden J. Studies on antibacterial, anti-inflammatory and antioxidant activity of herbal remedies used in the treatment of benign prostatic hyperplasia and prostatitis. J Ethnopharmacol. 2006; 103(1):71-5. [DOI:10.1016/j.jep.2005.07.007] [PMID]

[12] Hevesi BT, Houghton PJ, Habtemariam S, Kéry A. Antioxidant and antiinflammatory effect of Epilobiumparviflorumschreb. Phytother Res. 2009; 23(5):719-24. [DOI:10.1002/ptr.2725] [PMID]

[13] Şachir EE, Badea CF, Caraiane A, Raftu G, Badea V. On the phytochemical peculiarities and antibacterial activity of an aque- ous extract from Epilobium parviflorum schreb. Endodontics. 2019; 23(1):70-3. https://ijmd.ro/2019/vol-23-issue-1/on-thephytochemical-peculiarities-and-antibacterial-activity-of-anaqueous-extract-from-epilobium-parviflorum-schreb/

[14] Hiermann A, Juan H, Sametz W. Influence of Epilobium extracts on prostaglandin biosynthesis and carrageenin induced oedema of the rat paw. J Ethnopharmacol. 1986; 17(2):161-9. [DOI:10.1016/0378-8741(86)90055-3]

[15] Vitalone A, McColl J, Thome D, Costa LG, Tita B. Characterization of the effect of Epilobium extracts on human cell proliferation. Pharmacology. 2003; 69(2):79-87. [DOI:10.1159/000072360] [PMID]

[16] Stolarczyk M, Piwowarski JP, Granica S, Stefańska J, Naruszewicz M, Kiss AK. Extracts from Epilobium sp. herbs, their Components and gut microbiota metabolites of Epilobium ellagitannins, urolithins, inhibit hormone dependent prostate cancer cells-(LNCaP) proliferation and PSA secretion. Phytother Res. 2013; 27(12):1842-8. [DOI:10.1002/ptr.4941] [PMID]

[17] Slacanin I, Marston A, Hostettmann K, Delabays N, Darbellay C. Isolation and determination of flavonol glycosides from Epilobium species. J Chromat. 1991; 557:391-8. [DOI:10.1016/ S0021-9673(01)87147-8]

[18] Hevesi TB, Blazics B, Kéry Á. Polyphenol composition and antioxidant capacity of Epilobium species. J Pharm Biomed Anal. 2009; 49(1):26-31. [DOI:10.1016/j.jpba.2008.09.047] [PMID]

[19] ÇAliŞKan U, Dilşat DG, Memiş G. Effects of phyto-therapeutics on benign prostate hyperplasia. Ankara Universitesi Eczacilik Fakultesi Dergisi. 2019; 43(2):173-96. [DOI:10.33483/ jfpau.459798]

[20] Granica S, Piwowarski JP, Czerwińska ME, Kiss AK. Phytochemistry, pharmacology and traditional uses of different Epilobium species (Onagraceae): A review. J Ethnopharmacol. 2014; 156:316-46. [DOI:10.1016/j.jep.2014.08.036] [PMID]

[21] Sharifa A, Neoh YL, Iswadi MI. Effects of methanol, ethanol and aqueous extract of Plantago major on gram positive bacteria, gram negative bacteria and yeast. Annales of Microscopy. 2008; 8:42-4. https://www.sid.ir/en/journal/ViewPaper. aspx?ID=381102

[22] Mosmann T. Rapid colorimetric assay for cellular growth and survival: Application to proliferation and cytotoxicity assays. J Immunol Methods. 1983; 65(1-2):55-63. [DOI:10.1016/00221759(83)90303-4]

[23] Gelman A. Analysis of variance? Why it is more important than ever. Ann Stat. 2005; 33(1):1-53. [DOI:10.1214/0090536040 00001048]

[24] Moheghi N, Tavakkol Afshari J, Brook A. [The cytotoxic effect of zingiber afficinale in breast cancer (MCF7) cell line (Persian)]. Ofogh-e-Danesh. 2011; 17(3):28-34. http://hms.gmu.ac.ir/article-1-1282-en.html

[25] Watsone L, Dallwitz MJ. The families of angiosperms, automated descriptions with interactive identification and information retrieval. Aust Syst Bot. 1991; 4(4):681-95. [DOI:10.1071/ SB9910681]

[26] Arredondo MF, Blasina F, Echeverry C, Morquio A, Ferreira $\mathrm{M}$, Abin-Carriquiry JA, et al. Cytoprotection by Achyrocline satureioides (Lam) D.C. and some of its main flavonoids against oxidative stress. J Ethnopharmacol. 2004; 91(1):13-20. [DOI:10.1016/j.jep.2003.11.012] [PMID] 
[27] Kiss AK, Bazylko A, Filipek A, Granica S, Jaszewska E, Kiarszys $U$, et al. Oenothein B's contribution to the anti-inflammatory and antioxidant activity of Epilobium sp. Phytomedicine. 2011; 18(7):557-60. [DOI:10.1016/j.phymed.2010.10.016] [PMID]

[28] Toth Hevesi B, Kery A. Epilobium parviflorum in vitro study of biological action. Acta Pharm Hung. 2009; 79(1):3-9. [PMID]

[29] Paterniti I, Campolo M, Cordaro M, Siracusa R, Filippone A, Esposito E, et al. Effects of different natural extracts in an experimental model of Benign Prostatic Hyperplasia (BPH). Inflamm Res. 2018; 67(7):617-26. [DOI:10.1007/s00011-0181152-9] [PMID]

[30] Deng L, Zong W, Tao X, Liu S, Feng Z, Lin Y, et al. Evaluation of the therapeutic effect against benign prostatic hyperplasia and the active constituents from Epilobium angustifolium. J Ethnopharmacol. 2019; 232:1-10. [DOI:10.1016/j. jep.2018.11.045] [PMID]

[31] Chandra S, Lata H, Varma A Biotechnology for medicinal plants: Micropropagation and improvement. Heidelberg: Springer: 2013. https://www.springer.com/gp/ book/9783642299735

[32] Stolarczyk M, Naruszewicz M, Kiss AK. Extracts from Epilobium sp. Herbs induce apoptosis in human hormonedependent prostate cancer cells by activating the mitochondrial pathway. J Pharm Pharmacol. 2013; 65(7):1044-54. [DOI:10.1111/jphp.12063] [PMID]

[33] Srivilai J, Minale G, Scholfield CN, Ingkaninan K. Discovery of natural steroid 5-alpha-reductase inhibitors. Assay Drug Dev Technol. 2018; 17(2):44-57. [DOI:10.1089/ adt.2018.870] [PMID] 
This Page Intentionally Left Blank 